\title{
Rutin suppresses high glucose-induced ACTA2 and p38 protein expression in diabetic nephropathy
}

\author{
CHUN-SHAN HAN ${ }^{1}$, KAI LIU ${ }^{2}$, NING ZHANG ${ }^{3}$, SHI-WEN LI ${ }^{3}$ and HAI-CHENG GAO ${ }^{3}$ \\ ${ }^{1}$ Department of Chest Surgery, China-Japan Union Hospital of Jilin University, Changchun, Jilin 130033; ${ }^{2}$ Department \\ of Pathology and Pathophysiology, Chengde Medical College, Chengde, Hebei 300000; ${ }^{3}$ Department of Clinical \\ Pharmacy, Jilin University School of Pharmaceutical Sciences, Changchun, Jilin 130021, P.R. China
}

Received April 1, 2016; Accepted April 14, 2017

DOI: $10.3892 /$ etm.2017.4509

\begin{abstract}
The present study investigated the effect of rutin on high glucose-induced actin, $\alpha 2$, smooth muscle, aorta (ACTA2) and p38 protein expression in diabetic nephropathy (DN). Human mesangial cells were divided into a control group, high glucose-induced mesangial cell group, high glucose + captopril group, and high glucose + rutin group (low, middle and high doses of rutin). Cell viability, adenosine 5'-triphosphate (ATP) content, cell cycle, and ACTA2 and p38 protein expression were examined using MTT assay, ATP assay kit, flow cytometry and immunofluorescence staining in cultured human mesangial cells, respectively. Cell viability, ATP content, and ACTA 2 and p38 expression increased significantly in high glucose-induced mesangial cells $(\mathrm{P}<0.05)$. However, at concentrations of $0.2,0.4$ and $0.8 \mu \mathrm{mol} / 1$ rutin was able to inhibit high glucose-induced human mesangial cell viability, ATP content, and ACTA2 and $\mathrm{p} 38$ expression and improve the cell cycle progression of mesangial cells. In conclusion, ACTA 2 and p38 proteins may have important roles in DN. Rutin may inhibit the expression of ACTA2 and p38 and may be utilized in the prevention and treatment of DN.
\end{abstract}

\section{Introduction}

Diabetic nephropathy (DN) is one of the most serious microvascular complications of diabetes and a relatively common disease, which is the leading cause of end-stage renal disease (1-4). According to reports, the prevalence rate of $\mathrm{DN}$ is $33-40 \%$ in type 1 diabetes (5). The prevalence rate of DN is $20-25 \%$ in type 2 diabetes (6). Increasing research has focused on the genetics of lesion formation in the

Correspondence to: Professor Hai-Cheng Gao, Department of Clinical Pharmacy, Jilin University School of Pharmaceutical Sciences, 1266 Fujin Road, Changchun, Jilin 130021, P.R. China E-mail: gaohc@jlu.edu.cn

Key words: diabetic nephropathy, human mesangial cells, actin, $\alpha 2$, smooth muscle, aorta, p38, rutin coronary artery of patients with type 2 diabetes (7). Actin, $\alpha 2$, smooth muscle, aorta (ACTA2) is located on chromosome $10 \mathrm{q}(23.3)$ and is the most abundant $\alpha$ actin content of protein in vascular smooth muscle cells (8). ACTA2 accounts for $40 \%$ of the total protein in vascular smooth muscle cells, and $70 \%$ of total actin protein (9). Thus, ACTA2 is an important protein required for the contraction of vascular smooth muscle cells. p38 is a key component of mitogen-activated protein kinase-mediated signaling pathways, and is involved in a variety of physiological processes, including inflammation, proliferation and apoptosis (10). Rutin is a drug that has been used clinically for many years for the regulation of cardiovascular disease and for diabetes $(11,12)$. Therefore, the present study aimed to investigate whether rutin is able to inhibit the expression of p38 and ACTA2 and improve the severity of diabetic nephropathy. The protective effects of rutin on diabetic kidney disease were investigated by examining mesangial cell viability, energy metabolism, cell cycle and protein expression with the aim of providing valuable data for the clinical prevention and treatment of DN.

\section{Materials and methods}

Materials. ACTA2 (BM1693) and p38 (MK2101) antibodies were purchased from Wuhan Boster Biological Technology, Ltd. (Wuhan, China). G secondary antibodies (AP130P) were obtained from Sigma-Aldrich (Merck KGaA, Darmstadt, Germany). An MCO-5AC $\mathrm{CO}_{2}$ thermostat incubator was obtained from Sanyo Electric Biomedical Co., Ltd. (Tokyo, Japan).

Cell culture. Glomerular mesangial cells were provided by Jilin University School of Pharmaceutical Sciences (Changchun, China). Glomerular mesangial cells were divided into a control group (PBS washing), high glucose-induced group (incubation with DMEM high glucose to mimic an environment that would induce DN; Invitrogen; Thermo Fisher, Scientific, Inc., Waltham, MA, USA), high glucose + captopril group $(0.4 \mu \mathrm{mol} / 1,24 \mathrm{~h})$, and high glucose + low, middle and high rutin groups $(0.2,0.4$ and $0.8 \mu \mathrm{mol} / 1$ rutin, respectively). Cells were cultured in DMEM high glucose at $37^{\circ} \mathrm{C}$ in a humidified atmosphere containing $5 \% \mathrm{CO}_{2}$ for $24 \mathrm{~h}$. Cells in the high glucose + rutin groups were treated with rutin for 
$24 \mathrm{~h}$. Subsequently, mesangial cells were prepared for assays of cell viability, adenosine 5'-triphosphate (ATP) content, cell cycle, and ACTA2 and $\mathrm{p} 38$ protein expression levels.

Cell viability assay. A cell viability assay was carried out with an MTT staining kit (Sigma-Aldrich; Merck KGaA), according to the manufacturer's protocol. Results were analyzed using a spectrophotometer (UV2550; Shimadzu Corporation, Kyoto, Japan) at $450 \mathrm{~nm}$.

ATP content. Intracellular ATP was quantified using an ATP Assay Kit (S0026; Biyun Tian Biotechnology Research Institute). Cell suspension (100 $\mu \mathrm{l})$ was transferred to the wells of a 96-well microplate and ATP Assay reagent $(100 \mu \mathrm{l})$ was added. The plate was shaken using a plate shaker for $10 \mathrm{~min}$ and luminescence was measured using a spectrophotometer (UV2550, $450 \mathrm{~nm}$ ).

Cell cycle analysis. Glomerular mesangial cells were cultured in Dulbecco's modified Eagle's medium (Invitrogen; Thermo Fisher Scientific, Inc.) in $50-\mathrm{cm}^{2}$ plates $\left(1 \times 10^{6}\right.$ cells/well) for $24 \mathrm{~h}$ at $37^{\circ} \mathrm{C}$ then treated with $0.2,0.4$ and $0.8 \mu \mathrm{mol} / 1$ (low, medium and high) rutin. Following incubation for $24 \mathrm{~h}$, the cells were digested with $0.25 \%$ trypsin. DNA profiles were evaluated using a flow cytometry station (MACSQuant Analyzer, Miltenyi Biotec, Inc., Cambridge, MA, USA). Histograms or density plots were generated using the MACSQuant digital software.

Immunofluorescence and DAPI staining. Cells were fixed with $4 \%$ paraformaldehyde (Sigma-Aldrich; Merck KGaA) for $15 \mathrm{~min}$ at room temperature, then washed three times with PBS for $10 \mathrm{~min}$. Cells were incubated with ACTA2 (BM1693) and p38 (MK2101) antibodies (1:200) at $4^{\circ} \mathrm{C}$ overnight, washed three times for $5 \mathrm{~min}$ and subsequently incubated with anti-mouse immunoglobulin G secondary antibodies (1:500; AP130P; Sigma-Aldrich; Merck KGaA) at $4^{\circ} \mathrm{C}$ for $2 \mathrm{~h}$. DAPI was then used for nuclear staining. Cells were mounted and images were taken using a Nikon eclipse 80i fluorescence microscope (Nikon Corporation, Tokyo, Japan). The protein expression levels of ACTA2 and p38 and apoptotic cell count (DAPI) were analyzed using Image Pro Plus 6.0 software (Media Cybernetics, Inc., Rockbille, MD, USA).

Statistical analysis. All data were obtained from at least three independent experiments and presented as the mean \pm standard error of the mean. Statistical comparisons were made using Student's t-tests. Statistical analysis of the data was performed using SPSS v.11.0 for Windows (SPSS, Inc., Chicago, IL, USA). P $<0.05$ was considered to indicate a statistically significant difference.

\section{Results}

Mesangial cell viability. Mesangial cells were treated with different doses of rutin. Results demonstrated that cell viability was significantly increased in the high glucose-induced group at $24 \mathrm{~h}$ compared with the control group $(\mathrm{P}<0.01$; Fig. 1). However, cell viability was significantly reduced

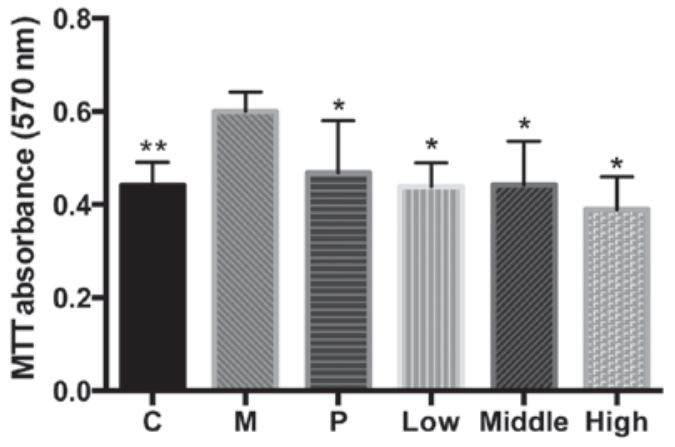

Figure 1. Mesangial cell viability. Data are presented as the mean \pm standard error of the mean. ${ }^{* *} \mathrm{P}<0.01$ and ${ }^{*} \mathrm{P}<0.05$ vs. $\mathrm{M}$. C, control group; $\mathrm{M}$, high glucose-induced group; P, captopril group; Low, group treated with $0.2 \mu \mathrm{mol} / 1 \mathrm{rutin}$; Middle, group treated with $0.4 \mu \mathrm{mol} / 1 \mathrm{rutin}$; High, group treated with and $0.8 \mu \mathrm{mol} / 1$ rutin.

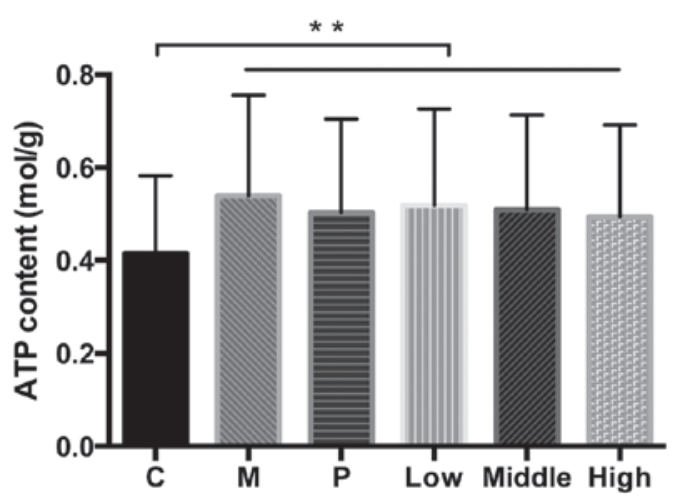

Figure 2. ATP content of mesangial cells. Data are presented as the mean \pm standard error of the mean. ${ }^{* *} \mathrm{P}<0.01$. ATP, adenosine 5 '-triphosphate; C, control group; M, high glucose-induced group; P, captopril group; Low, group treated with $0.2 \mu \mathrm{mol} / 1 \mathrm{rutin}$; Middle, group treated with $0.4 \mu \mathrm{mol} / 1$ rutin; High, group treated with and $0.8 \mu \mathrm{mol} / 1$ rutin.

after treatment with rutin (low, middle and high doses) and captopril $(\mathrm{P}<0.05)$ compared with high glucose-induced cells. These results indicated that rutin was able to inhibit the viability of mesangial cells.

ATP content analysis. The present results demonstrated that ATP content was significantly increased in all high glucose-induced mesangial cells compared with the control cells $(\mathrm{P}<0.05$; Fig. 2$)$.

Cell cycle analysis. Flow cytometry was performed following treatment of mesangial cells with $0.2,0.4$ and $0.8 \mu \mathrm{mol} / 1 \mathrm{rutin}$ for $24 \mathrm{~h}$. Results demonstrated that the cell cycle of mesangial cells changed markedly in the high glucose-induced mesangial cells group. However, the cell cycle progression of mesangial cells improved markedly in cells treated with rutin (Fig. 3; Table I). These results suggested that rutin may affect the regulation of the mesothelial cell cycle.

Immunofluorescence staining. As demonstrated in Fig. 4 and Table II, the experimental results indicated apoptotic morphological changes of mesangial cells after $24 \mathrm{~h}$ rutin treatment was observed by fluorescence microscopy. Relative 
Table I. Cell cycle distribution in each group of mesangial cells.

\begin{tabular}{lcrr}
\hline Group & G1, $\%$ & G2, \% & S, \% \\
\hline Control & 83.60 & 3.13 & 13.30 \\
High glucose-induced & 80.40 & 8.21 & 11.40 \\
Captopril & 81.70 & 6.84 & 11.50 \\
Rutin $(0.2 \mu \mathrm{mol} / \mathrm{l})$ & 85.00 & 1.08 & 13.90 \\
Rutin $(0.4 \mu \mathrm{mol} / \mathrm{l})$ & 82.70 & 7.94 & 9.29 \\
Rutin $(0.8 \mu \mathrm{mol} / \mathrm{l})$ & 80.80 & 7.79 & 11.50 \\
& & &
\end{tabular}

A

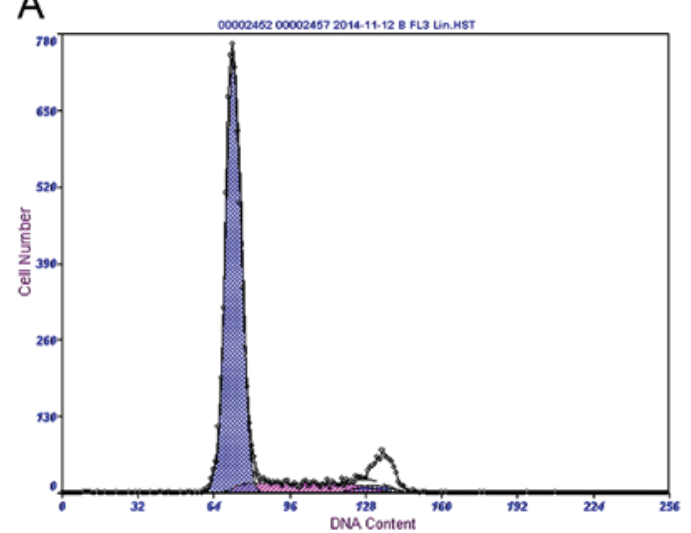

C

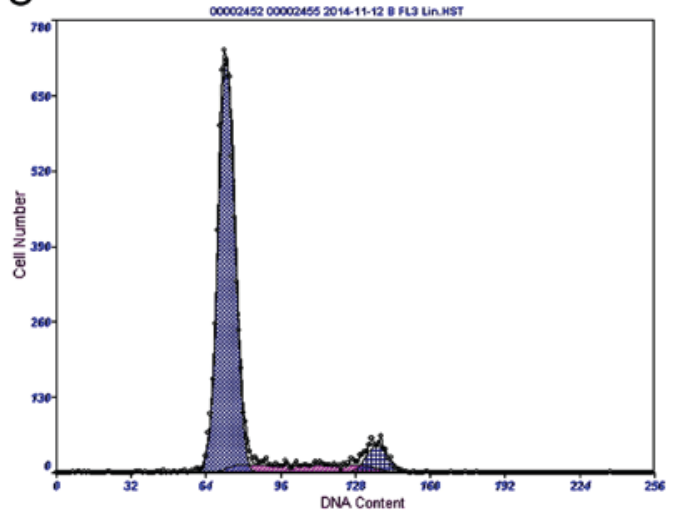

E

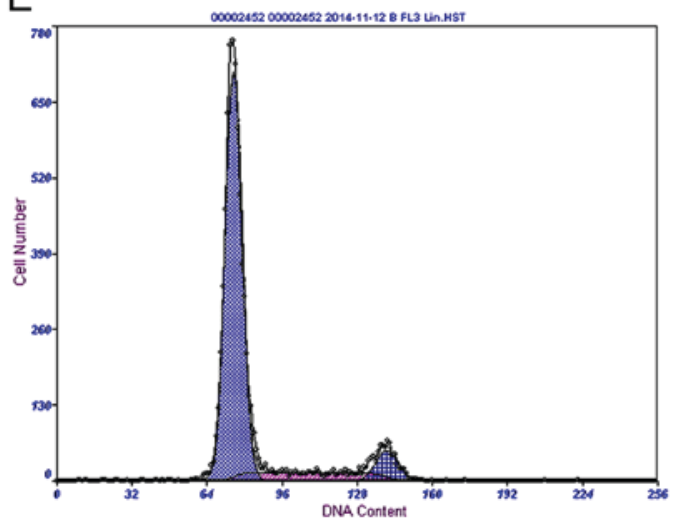

B

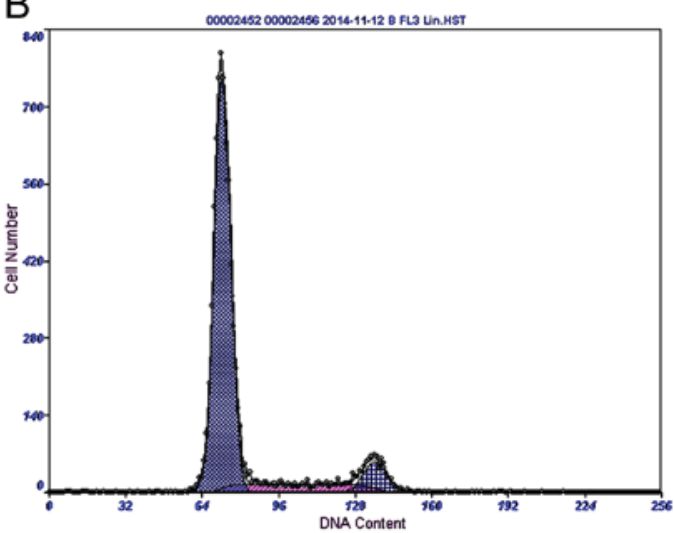

D

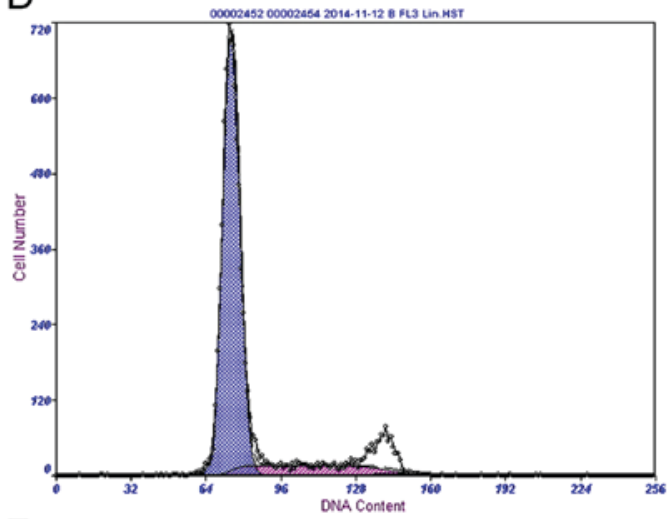

$\mathrm{F}$

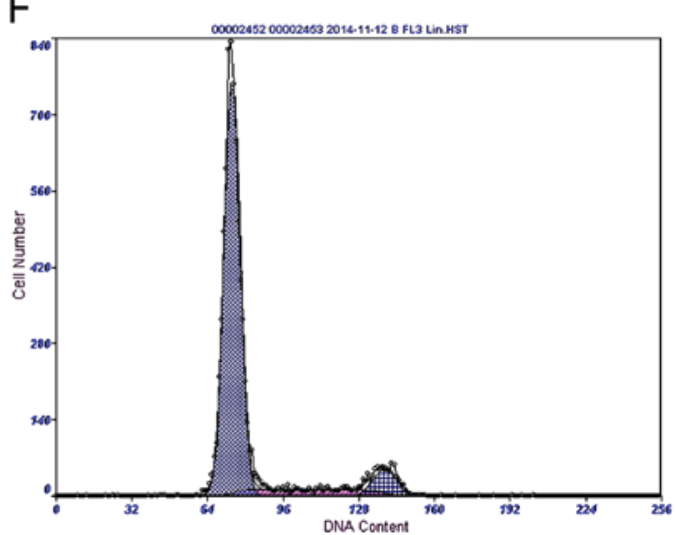

Figure 3. Cell cycle analysis in each group of mesangial cells. Cell cycle analysis of the (A) control, (B) high glucose-induced, (C) captopril group and (D) 0.2 (low), (E) 0.4 (middle) and (F) $0.8 \mu \mathrm{mol} / 1$ (high) rutin treatment groups.

to the control group, cell groups treated with rutin exhibited higher numbers of detached cells with round and shrunken morphologies. DAPI nuclear staining also identified signs of mesangial cell apoptosis in the rutin treatment groups. 
Table II. ACTA2 and p38 protein expression in each mesangial cell group (\%).

\begin{tabular}{lrrr}
\hline Group & Nucleus & ACTA2 & p38 \\
\hline Control & $10.27 \pm 1.19$ & $18.047 \pm 0.81$ & $12.543 \pm 0.24$ \\
High glucose-induced & $25.22 \pm 1.75^{\mathrm{a}}$ & $28.41 \pm 1.92^{\mathrm{a}}$ & $26.85 \pm 0.11^{\mathrm{a}}$ \\
Captopril & $12.26 \pm 0.97^{\mathrm{b}}$ & $22.57 \pm 1.36^{\mathrm{b}}$ & $17.05 \pm 0.60^{\mathrm{b}}$ \\
Rutin $(0.2 \mu \mathrm{mol} / \mathrm{l})$ & $17.92 \pm 1.79^{\mathrm{b}}$ & $25.61 \pm 1.66^{\mathrm{b}}$ & $22.63 \pm 0.72^{\mathrm{b}}$ \\
Rutin $(0.4 \mu \mathrm{mol} / \mathrm{l})$ & $17.84 \pm 2.35^{\mathrm{b}}$ & $35.60 \pm 2.53$ & $19.26 \pm 0.65^{\mathrm{b}}$ \\
Rutin $(0.8 \mu \mathrm{mol} / \mathrm{l})$ & $14.63 \pm 1.09^{\mathrm{b}}$ & $20.77 \pm 1.40^{\mathrm{b}}$ & $19.93 \pm 0.73^{\mathrm{b}}$
\end{tabular}

Data are presented as the mean \pm standard error of the mean. ${ }^{\mathrm{a}} \mathrm{P}<0.05$ vs. control group; ${ }^{\mathrm{b}} \mathrm{P}<0.05$ vs. high glucose-induced group. ACTA2, actin, $\alpha^{2}$, smooth muscle, aorta.
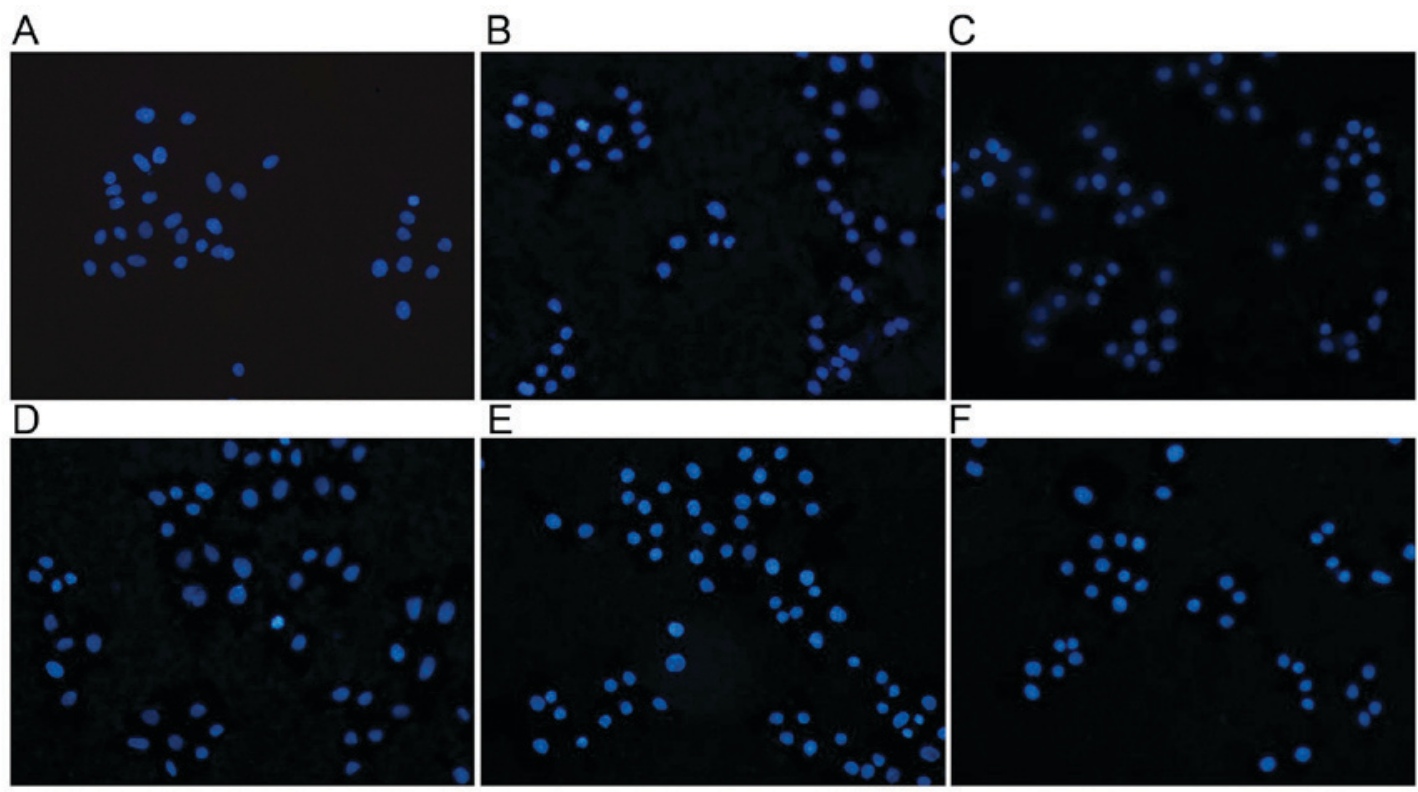

Figure 4. Immunofluorescence staining with DAPI. Immunofluorescence images from the (A) control, (B) high glucose-induced, (C) captopril group and (D) 0.2 , (E) 0.4 and (F) $0.8 \mu \mathrm{mol} / 1$ rutin treatment groups. Magnification, $\mathrm{x} 200$.

ACTA2 protein expression. To validate the expression of ACTA2 in mesangial cells, ACTA2 specific fluorescent staining was performed on mesangial cells. The results demonstrated that cells in the control group had uniform chromatin, with a large nucleus and that they maintained integrity of the nuclear envelope. Expression of ACTA2 protein increased significantly in the high glucose group compared with the control $(\mathrm{P}<0.05$; Fig. 5; Table II). The expression of ACTA2 protein decreased significantly in the rutin groups at $24 \mathrm{~h}$ compared with the high glucose group $(\mathrm{P}<0.05$; Fig. 5 ; Table II), with the exception of the middle dose of rutin group.

p38 protein expression. To validate the expression of $\mathrm{p} 38$ in mesangial cells, p38 specific fluorescent staining was performed on mesangial cells. The results demonstrated that cells in the control group had uniform chromatin, a large nucleus and maintained integrity of the nuclear envelope. The expression of $\mathrm{p} 38$ protein increased significantly in high glucose group compared with the control $(\mathrm{P}<0.05$; Fig. 6;
Table II). The expression of $\mathrm{p} 38$ protein decreased significantly in the rutin groups at $24 \mathrm{~h}$ compared with the high glucose group $(\mathrm{P}<0.05$; Fig. 6; Table II).

\section{Discussion}

$\mathrm{DN}$ is one of the most serious microvascular complications of diabetes (13). Glucose metabolism and renal hemodynamics have an important role in the pathogenesis of DN (14). In the present experiment, high glucose induced the viability of mesangial cells. Rutin inhibited the viability of high glucose-induced mesangial cells. These results indicated that rutin had hypoglycemic effects. ATP is a versatile nucleotide and has an important role in cell biology as a coenzyme that is the 'molecular unit of currency' of intracellular energy transfer (15). The present experiment demonstrated that ATP content increased in high glucose-induced mesangial cells, indicating that high glucose may induce a change in ATP content. The content of ATP decreased after intervention with rutin. Therefore, rutin may have a hypoglycemic effect 

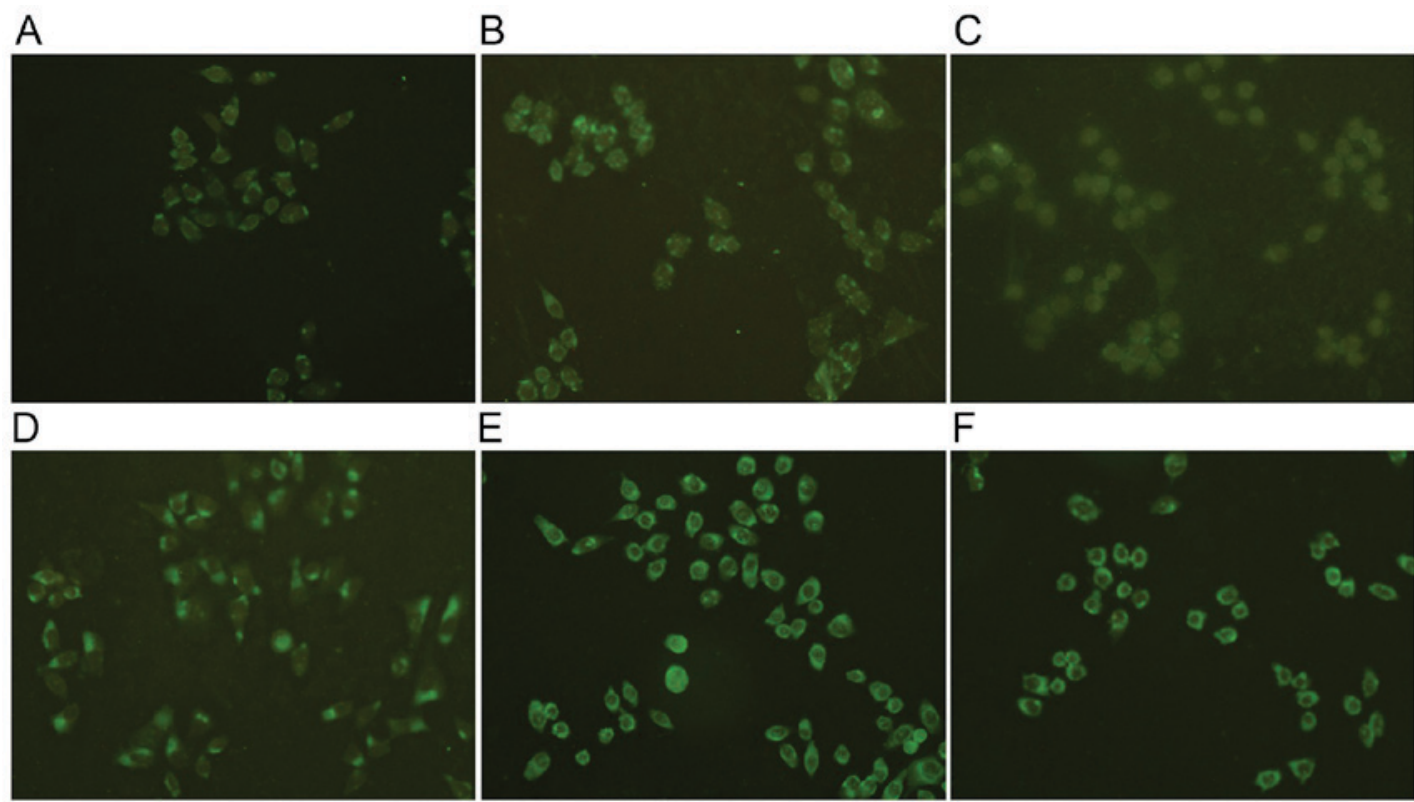

E

$\mathrm{F}$
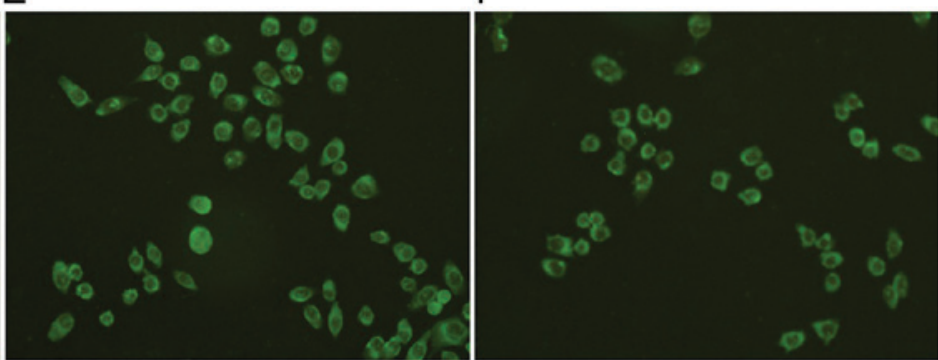

Figure 5. ACTA2 protein expression in the different mesangial cell groups. ACTA2 protein expression in the (A) control, (B) high glucose-induced, (C) captopril group and (D) 0.2 , (E) 0.4 and (F) $0.8 \mu \mathrm{mol} / 1$ rutin treatment groups. ACTA2, actin, $\alpha 2$, smooth muscle, aorta. Magnification, x200.

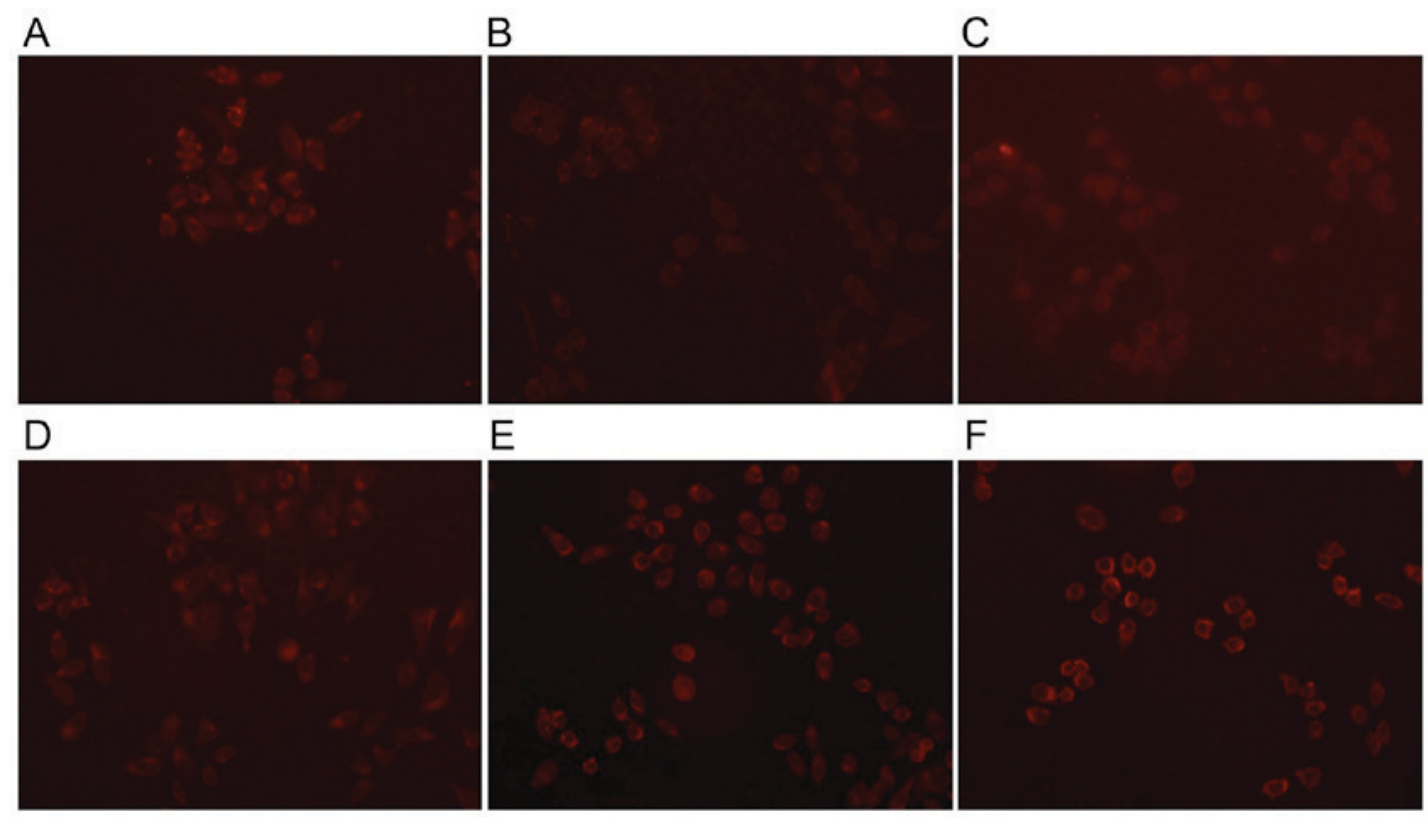

Figure 6. p38 protein expression in the different mesangial cell groups. p38 protein expression in the (A) control, (B) high glucose-induced, (C) captopril group and (D) 0.2 , (E) 0.4 and (F) $0.8 \mu \mathrm{mol} / 1$ rutin treatment groups. Magnification, $\mathrm{x} 200$.

on cells and regulate energy metabolism. ACTA2 exists in birds and mammals. ACTA2 is predominantly distributed in vascular myofibroblastic cells, myoepithelial cells and smooth muscle cells under normal circumstances (16).

In the present experiment, the expression of ACTA2 increased in high glucose-induced mesangial cells. Expression of ACTA2 reduced after treatment with rutin. These results indicated that rutin may inhibit the expression of ACTA2 protein and protect against DN. p38 protein kinase is able to promote leukocyte aggregation and activation, regulate the activity of transcription factors and the synthesis of cell factors, and it has an important role in the regulation of inflammatory reactions (17). In the present experiment, the expression of p38 increased in high glucoseinduced mesangial cells. p38 expression decreased after treatment with rutin. These results indicated that rutin may inhibit the expression of $\mathrm{p} 38$ protein, with protective effects against DN.

In conclusion, a diabetic model was successfully induced by high glucose, which promoted glomerular cell viability, increased ATP content, induced changes in the cell cycle, and increased the expression of ACTA2 and p38 proteins. Results suggested that rutin has hypoglycemic effects. Rutin may inhibit the expression of ACTA2 and p38 and may 
confer protective effects against DN. Rutin may also regulate the expression of $\mathrm{p} 38$.

\section{Acknowledgments}

The present study was supported by the Science and Technology Department of Jilin Province, China (grant nos. 20140312002ZG and YYZX201259).

\section{References}

1. Park CW: Diabetic kidney disease: From epidemiology to clinical Perspectives, Diabetes Metab J 38: 252-260, 2014.

2. Brennan E, McEvoy C, Sadlier D, Godson C and Martin F: The genetics of diabetic nephropathy. Genes (Basel) 4: 596-619, 2013.

3. Bansal D, Badhan Y, Gudala K and Schifano F: Ruboxistaurin for the treatment of diabetic peripheral neuropathy: A systematic review of randomized clinical trials. Diabetes Metab J 37: 375-384, 2013

4. Ding Y and Choi ME: Autophagy in diabetic nephropathy. J Endocrinol 224: R15-R30, 2015.

5. Bellastella G, Maiorino MI, Olita L, Della Volpe E, Giugliano D and Esposito $\mathrm{K}$ : Premature ejaculation is associated with glycemic control in Type 1 diabetes. J Sex Med 12: 93-99, 2015.

6. Ono K, Limbu YR, Rai SK, Kurokawa M, Yanagida J, Rai G, Gurung N, Sharma M and Rai CK: The prevalence of type 2 diabetes mellitus and impaired fasting glucose in semi-urban population of Nepal. Nepal Med Coll J 9: 154-156, 2007.

7. Stolk RP, van Schooneveld MJ, Cruickshank JK, Hughes AD, Stanton A, Lu J, Patel A, Thom SA, Grobbee DE and Vingerling JR; AdRem Project Team and ADVANCE Management Committee: Retinal vascular lesions in patients of Caucasian and Asian origin with type 2 diabetes: Baseline results from the ADVANCE Retinal Measurements (AdRem) study. Diabetes Care 31: 708-713, 2008.
8. Kurpinski K, Lam H, Chu J, Wang A, Kim A, Tsay E, Agrawal S, Schaffer DV and Li S: Transforming growth factor-beta and notch signaling mediate stem cell differentiation into smooth muscle cells. Stem Cells 28: 734-742, 2010.

9. Whitesell TR, Kennedy RM, Carter AD, Rollins EL, Georgijevic S, Santoro MM and Childs SJ: An $\alpha$-smooth muscle actin (acta2/asma) zebrafish transgenic line marking vascular mural cells and visceral smooth muscle cells. PLoS One 9: e90590, 2014.

10. Yang Y, Kim SC, Yu T, Yi YS, Rhee MH, Sung GH, Yoo BC and Cho JY: Functional roles of p38 mitogen-activated protein kinase in macrophage-mediated inflammatory responses. Mediators Inflamm 2014: 352371, 2014.

11. Wang YB, Ge ZM, Kang WQ, Lian ZX, Yao J and Zhou CY: Rutin alleviates diabetic cardiomyopathy in a rat model of type 2 diabetes. Exp Ther Med 9: 451-455, 2015.

12. Panchal SK, Poudyal H, Arumugam TV and Brown L: Rutin attenuates metabolic changes, nonalcoholic steatohepatitis, and cardiovascular remodeling in high-carbohydrate, high-fat diet-fed rats. J Nutr 141: 1062-1069, 2011.

13. Soetikno V, Arozal W, Louisa M and Setiabudy R: New insight into the molecular drug target of diabetic nephropathy. Int $\mathrm{J}$ Endocrinol 2014: 968681, 2014.

14. Sanjuliani AF, Fagundes VG and Francischetti EA: The effect of urapidil on blood pressure, renal hemodynamics, lipid and glucose metabolism. Arq Bras Cardiol 65: 59-63, 1995 (In Portuguese).

15. Barata $\mathrm{H}$ and de Meis L: Uncoupled ATP hydrolysis and thermogenic activity of the sarcoplasmic reticulum $\mathrm{Ca}^{2+}$-ATPase: Coupling effects of dimethyl sulfoxide and low temperature. J Biol Chem 277: 16868-16872, 2002.

16. Guo DC, Pannu H, Tran-Fadulu V, Papke CL, Yu RK, Avidan N, Bourgeois S, Estrera AL, Safi HJ, Sparks E, et al: Mutations in smooth muscle alpha-actin (ACTA2) lead to thoracic aortic aneurysms and dissections. Nat Genet 39: 1448-1493, 2007.

17. Lin YL, Liang YC, Lee SS and Chiang BL: Polysaccharide purified from Ganoderma lucidum induced activation and maturation of human monocyte-derived dendritic cells by the NF-kappaB and p38 mitogen-activated protein kinase pathways. J Leukoc Biol 78: 533-543, 2005. 